\title{
Boolean and fuzzy methods for identifying lateritic regoliths in the Brazilian Amazon using gamma-ray spectrometric and topographic data
}

\author{
Edgar Romeo Herrera de Figueiredo Iza ${ }^{\text {a,b,* }}$, Adriana Maria Coimbra Horbe ${ }^{\text {b }}$, Adalene Moreira Silva ${ }^{\text {b }}$ \\ a Serviço Geológico do Brasil-CPRM, Av. Lauro Sodré, 2561, São Sebastião, Porto Velho 76801-581, Brazil \\ b Instituto de Geociências, Universidade de Brasília, Campus Universitário Darcy Ribeiro, Brasília 70910-900, Brazil
}

\section{A R T I C L E I N F O}

Article history:

Received 20 July 2015

Received in revised form 11 January 2016

Accepted 23 January 2016

Available online 1 February 2016

\section{Keywords:}

Lateritic crust

Relief

Geomorphology

Modeling

Oxisol

\begin{abstract}
A B S T R A C T
Airborne gamma-ray spectrometry is relatively well understood when associated with rocks, but the response and radioelement distribution in weathered materials is less known. This work used airborne gamma-ray spectrometry and altimetry to identify domains with higher probability of occurrence of lateritic crust and dismantling products in an area located in the west of the Brazilian Amazon. Map algebra was used through the Boolean and fuzzy techniques to create predictability digital models highlighting favorable areas for the occurrence of lateritic crusts. The Index Overlay Method was used in the Boolean technique. The fuzzy technique used the fuzzy algebraic product operator, fuzzy algebraic sum operator, and fuzzy gamma operator. Both models showed good correlation between the favorability predicted and the presence of crusts in the field, however, the fuzzy model showed higher correlation and highlighted areas not identified by the Boolean model. In contrast, the Boolean model allowed the visualization of the areas related to the influence of each variable or its possible combinations individually on the final map. Thus, the identification of lateritic crusts based on mathematic models applied to altimetric and airborne gamma-ray spectrometric data is a new tool that will contribute significantly to geological mapping and to the understanding related to the response and radioelement distribution in weathered materials.
\end{abstract}

(c) 2016 Elsevier B.V. All rights reserved.

\section{Introduction}

Throughout Earth's geological history, weathering has been an important process for the modification of the landscape and formation of soils and mineral deposits and has also had a significant impact on controlling the relief and reflecting paleoclimatic variations. In humid tropical climates, lateritic crusts are the final product of weathering (Bardossy and Aleva, 1989; Tardy and Roquin, 1998). The lateritic crusts in the Amazon and along the intertropical belt are related to the Cenozoic (Lucas et al., 1989; Nahon et al., 1989; Boulangé and Carvalho, 1997; Costa, 1997; Horbe and Da Costa, 1999; Kotschoubey et al., 2005; Horbe and Da Costa, 2005).

Climate, relief, parent rock, time, and tectonics are among the main factors that affect intensity of the weathering and erosion processes; thus, these factors are strongly related to geomorphologic aspects. Thomas (1974) stated that climate is an important factor regulating weathering and therefore it determines the nature and speed of the chemical reactions on the Earth's surface. Pomerol et al. (2013) noted that the main factors related to relief evolution are tectonics and climate, whose actions are measured by long geological intervals.

\footnotetext{
* Corresponding author.

E-mail addresses: edgar.iza@cprm.gov.br (E.R.H.F. Iza), ahorbe@unb.br (A.M.C. Horbe), adalene@unb.br (A.M. Silva).
}

Aleva (1993) and Anand and Paine (2002) noted that the lateritization process is favored by alternation between dry and wet seasons. Within this context, these authors also noted that the water table fluctuates; such fluctuations promote alternations between more or less oxidizing conditions, favor successive iron remobilization, concentrate the iron, and thus lead to the generation of ferruginous nodules. Iron accumulates during lateritization, residually forming lateritic crusts. In arid conditions, the lateritic crust tends to be preserved, thus maintaining the planation paleosurfaces, making such crusts excellent paleogeomorphologic records. In contrast, the permanent humid regime leads to intense chemical leaching and reduced water table fluctuations, thus interrupting the formation of the mottled zone and accelerating saprolite formation and degradation of the lateritic crust, which leads to the generation of oxisols. Horbe and Da Costa (2005) demonstrated the direct relationship between the lateritic crust and the overlying oxisol through textural, mineralogical, and chemical arguments and noted that the latter could be derived from the chemical alteration and consequent disaggregation of the crusts.

Taylor and Eggleton (2001) discussed climatic and topographic factors in the construction of the landscape and exploration of regoliths, particularly for $\mathrm{Al}, \mathrm{Fe}, \mathrm{Mn}, \mathrm{Ni}, \mathrm{Cu}, \mathrm{Pb}$, and $\mathrm{Au}$, in addition to aggregates for civil construction. According to McFarlane (1976); Büdel (1982); Butt and Zeegers (1992), and Beauvais (1999), among others, the study of regoliths and mapping of lateritic crusts aids in the understanding of 
geomorphologic and paleoclimatic evolution and the identification of anomalous metallogenic occurrences.

The lateritic crusts in the Amazon have not been mapped at adequate scales or are located in areas with limited access. Moreover, in this region as well as other parts of Brazil, lateritic crusts have been mapped as undifferentiated sedimentary covers, which include products such as the lateritic crust itself, oxisols, nodules and pisoliths and other dismantling products. In some of these areas, there are records of several mineral occurrences, such as $\mathrm{Ni}-\mathrm{Co}$ and $\mathrm{Cu}-\mathrm{Ni}$-EGP, and artisanal gold mining (Rizzotto, 2010, 2012a,b). Therefore, the identification and discrimination of lateritic crusts is essential in mineral exploration and useful for the improvement of geological mapping.

The use of the airborne gamma-ray spectrometry and altimetric data in regolith studies must be investigated, especially when applied with mathematical techniques, raster image algebra, and in the evaluation of multi-source data (e.g., Darnley and Grasty, 1971, Tucker et al., 1984, Duval, 1990, Burrough et al., 1992, Graham and Bonham-Carter, 1993, Wilford et al., 1997, Dickson and Scott, 1997, McKenzie \& Ryan 1999, Zhu et al., 2010, Carrino et al., 2011, Wilford, 2012 and Dent et al., 2013).

Airborne gamma-ray spectrometry measures the concentration of potassium (K) and series of uranium $(\mathrm{U})$ and thorium (Th) radioisotopes in rocks and soils at depths of 30-45 cm (Gregory and Horwood, 1961; Dickson and Scott, 1997). The intensity of gamma rays emitted from the surface depends on the mineral composition of the rock or regolith, nature and type of weathering, geological heterogeneity, distribution of allochthonous or autochthonous soils and vegetal cover, and humidity, among other factors (Wilford et al., 1997; Minty, 1997; Dickson and Scott, 1997). In general, eU, eTh, and K are the only elements that occur naturally and produce gamma rays with sufficient energy and intensity to be measured by airborne gamma-ray spectrometry (Minty, 1997).

Potassium is the most abundant radioisotope in Earth's crust; it has an average concentration of $2.4 \%$ and is generally present with high and low contents in felsic rocks and mafic rocks, respectively (Dickson and Scott, 1997, Minty, 1997). Potassium released during weathering can be partially fixed as illite. In contrast, $U$ and Th are relatively rare compared with K, varying between 3 and 12 ppm on average. Uranium can occur as uraninite and uranothorite, whereas Th can form thorite and may be present in allanite, monazite, xenotime, and zircon at levels higher than 1000 ppm (Dickson and Scott, 1997).

During weathering, radioelements are redistributed due to geochemical reorganization. They can accumulate residually and combine to form stable to weathering minerals, such as monazite, xenotime, zircon, and thorite; alternatively, they can be incorporated into newly formed minerals, such as iron and titanium oxides and hydroxides and clay minerals, or leached. In many cases, this redistribution generates different spectrometric responses for the regolith and underlying bedrock. Dickson and Scott (1997) suggested that areas with lateritic crust tend to have low $\mathrm{K}$ contents and relative high Th and $\mathrm{U}$ contents. Moreover, Wilford et al. (1997) stated that ferruginous duricrusts, particularly those developed over greenstone, are radiometrically barren (they appear black) in a ternary RBG diagram (KThU).

Wilford et al. (1997) noted that airborne gamma-ray spectrometry is relatively well understood when associated with rocks, but the response and radioelement distribution in weathered materials is less known. Traditional geological and soil mapping can be easily performed when the area is accessible with several outcrops; otherwise, remote tools must be used to reach inaccessible areas, including Indian reservations, deep forests, areas with no roads, and areas where the lateritic crust is covered by soil. Among remote tools, remote sensing and airborne gamma-ray spectrometry can be used to provide important information that may be difficult to collect with other techniques. In accessible areas, these tools can be used as a support in the planning phase of field works, saving field time by increasing the mapping efficiency. Gamma spectrometric data are advantageous in that they provide the radioactive signatures of eTh, eU, and \% $\mathrm{K}$, which provide additional information for geologic mapping and can be used as a complementary tool.
The purpose of this work was to use airborne gamma-ray spectrometry and altimetry to identify geophysical and topographic parameters for the delimitation of domains with a higher probability of occurrence of lateritic crust and dismantling products. Boolean and fuzzy techniques are compared using relief and geophysical data (eTh/K, eU/K), with the aim of facilitating field work and improving the final cartographic products.

\section{Materials and methods}

The altimetric base used in this study was the Shuttle Radar Topography Mission (SRTM) performed in 2000, which had a spatial resolution of $30 \mathrm{~m}$. The airborne gamma-ray spectrometric images were obtained by FUGRO AIRBORNE SURVEYS for the CPRM/Geological Survey of Brazil in the 2005-2006 period (refer to the airborne geophysical survey "Sudeste de Rondônia - RO" CPRM, 2006 for further information). The data were processed by LASA Prospecções S.A. and involved the application of routines in Oasis Montaj software, version 8.2.0.5, with minimum curvature interpolators and grid cells of $125 \mathrm{~m}$. The main products generated from the interpolation were individual images of the eU, eTh, and $\mathrm{K}$ channels and the ratios $\mathrm{eU} / \mathrm{K}$ and $\mathrm{eTh} / \mathrm{K}$. These products allowed for the generation of the ternary composition of $\mathrm{K}$, eTh, and eU (RGB) as well as eTh/K, SRTM and eU/K (RGB) images. The software used to integrate the data was ArcGIS 10.2 with the Geosoft extension that allowed the processing of the airborne geophysical images and the integrated handling of all of the products. The statistic data were processed and interpreted using Statistica 12 software.

The method developed in this work used airborne geophysical (gamma-ray spectrometric), and elevation (SRTM) images, which were analyzed using Boolean and fuzzy mathematical modeling techniques to create predictability maps for the occurrence of lateritic crusts and verify which of the techniques is more efficient. The theoretical base was extracted from An et al. (1991); Zimmermann (1985); Bonham-Carter (1994); Moreira et al. (2003); McBratney et al. (2003); Lagacherie (2005); Carranza (2008); Carrino et al. (2011) and da Silva et al. (2015). However, some modifications were performed to improve the results.

The modeling process consisted of a series of procedures to obtain a simplified hypothetical vision of the studied attributes and the Boolean and fuzzy techniques were used. These techniques are closely related to knowledge-driven models, i.e., models based on previous information or even hypotheses obtained by an expert (Bonham-Carter, 1994 and Carranza, 2008). Field work was performed to verify and calibrate the models presented, and the geologic maps from Quadros and Rizzotto (2007) and Rizzotto (2010, 2012a) and the map of soils from the Brazilian Institute of Geography and Statistic (IBGE - Instituto Brasileiro de Geografia e Estatística) were used as support.

The kappa coefficient $(\kappa)$ was computed to determine the concordance intensity between the models (predictability maps) and field data. The data used consist of information collected during field work for this research, as well as files stored in the GEOBANK (Geological Survey of Brazil database) available online at www.cprm.gov.br. To calculate the coefficient, 875 checkpoints were considered, classified as lateritic crust and non-lateritic materials.

The kappa coefficient is defined as $\kappa=\left(n \sum_{i=1}^{c} x_{i i}-\sum_{i=1}^{c} x_{i+} x_{+i}\right) /$ $\left(n^{2}-\sum_{i=1}^{c} x_{i+} x_{+i}\right)$, where $\mathrm{x}_{\mathrm{ii}}$ is the value on line $\mathrm{i}$ and column $\mathrm{i}, \mathrm{x}_{\mathrm{i}}$ is the sum of line $i, x_{+i}$ is the sum of column $i$ of the confusion matrix, $\mathrm{n}$ is the total number of samples and $\mathrm{c}$ is the number of classes (Cohen, 1960). According to Landis and Koch (1977), kappa is considered to have a nearly perfect agreement when it is above 0.81 and reaches 1 . Substantial agreement is obtained when kappa lies within the interval $0.61-0.80$. Kappa values below 0.60 are classified as moderate agreement, with values near zero indicating poor agreement. 


\subsection{Boolean logic}

Boolean logic is a mathematical system used to create logic rules or expressions to select, analyze, and process data. Bonham-Carter (1994) improved the Boolean technique through the index overlay method (IOM), which consists of granting different weights to each input map considering the level of importance according to the hypothesis. The outcomes include scores appropriate for mapping. The objective is to produce a map showing areas that are arranged according to the score, with a greater spectrum of results (Bonham-Carter, 1994).

Maps in binary format ( 0 and 1 ) were obtained in the Boolean analysis (algebraic binary map technique) and use the ratios eTh/K and eU/ $\mathrm{K}$ as well as the altimetric intervals (obtained from the SRTM image). The ratios were used to emphasize the discrepancies and highlight favorable areas associated with ferruginous crusts. Higher values of $\mathrm{eTh} / \mathrm{K}$ and $\mathrm{eU} / \mathrm{K}$ (equal or higher than the average plus one and a half times the standard deviation) are associated with a higher probability of the occurrence of lateritic crusts and were therefore transformed into " 1 "; in contrast, the lower values were transformed into " 0 ", generating new reclassified images ( 0 and 1 ) for both ratios.

In contrast, the procedure with the SRTM elevation model (relief) used a value of " 1 " for elevations lower than $300 \mathrm{~m}$ and higher than $500 \mathrm{~m}$ and a value of " 0 " for elevations between 301 and $499 \mathrm{~m}$. The first altimetric interval $(<300 \mathrm{~m})$ is associated with the domain where the geological unit called undifferentiated sedimentary covers is predominant and some lateritic outcrops are found. The second altimetric interval $(>500 \mathrm{~m})$, where the major lateritic bodies are mapped, is mainly associated with the sandstones of the Parecis Basin.

\subsubsection{Weight determination}

In the IOM, a weight is given to each input map according to the hypothesis considered. Each map is multiplied by its respective weight, summed, and finally normalized by the sum of weights. The final result is represented by values between 0 and 1 (BonhamCarter, 1994), which are appropriate for mapping. The equation for the IOM is $S=\left(\sum_{i}^{n} W_{i}\right.$ class $\left.\left(M A P_{i}\right)\right) /\left(\sum_{i}^{n} W_{i}\right)$, where $W i$ is the weight of the i-th map, class (MAPi) represents the input map of the $\mathrm{i}$-th variable and $\mathrm{n}$ is the number of variables.

Four cases using the three main variables (eTh/K, eU/K, and relief) were proposed to clarify the application of the IOM and determine the best combination of weights. In all cases, the scores vary between 0 and 1 and indicate areas with the lowest (0) and highest probabilities (1) of finding lateritic crust. The final choice of the best combination of weights was the one that separated the set of variables into favorable or unfavorable classes according to score, enabling the best visual differentiation of each score. The procedures performed in the Boolean logic included several stages and produced a final predictability map (see Fig. 1).

\subsection{Fuzzy logic}

Fuzzy logic provides the base for the generation of powerful techniques for modeling spatial data and digital maps. It allows conclusions to be obtained and responses to be generated from information that can be ambiguous or inaccurate (Torres, 2014). In this work, fuzzy logic was applied to the same variables as Boolean logic. The raw data were rasterized and then simplified using fuzzification, which allowed for staggering in the degrees of variability or pertinence between "0" (absent pertinence) and " 1 " (total pertinence). The use of the large and linear fuzzy membership functions allowed for the reorganization of the rasterized digital maps according to the type of input. The linear function was applied to the relief map, which keeps the original data, only rescaling between 0 and 1 , whereas the large function (favoring high values) was applied to the eTh/K and eU/K maps.

The gamma spectrometric data exhibit high values of eTh/K and eU/ $\mathrm{K}$ on the inferior and superior surfaces. These high values can be explained by the strong association with oxisols and lateritic crusts. The large membership function was applied to these images to highlight the high values and consequently the areas with a higher probability of crust occurrence.

The linear function was applied to the relief, as applying any of the other functions (e.g., large, small, pi-shaped) potentializes (overvalues) or minimizes (underestimates) areas considered undesirable or desirable, respectively, for the model. Using a small membership function on the relief overvalues the areas on the inferior surface $(<300 \mathrm{~m})$ and underestimates areas on the superior surface $(>500 \mathrm{~m})$, whereas a large membership function overvalues areas on the superior surface $(>500 \mathrm{~m})$ and underestimates areas on the inferior surface $(<300 \mathrm{~m})$. The inverse pi-shaped membership function overvalues both low and high altitude areas, and as a result, it highlights the same areas of the small and large functions simultaneously. Thus, when these membership functions are applied to the relief and integrated with gamma spectrometry images, the areas highlighted as favorable are overly extensive and do not represent the best option for the construction of the model.

The following step was performed to combine the fuzzified maps and reorganize them using fuzzy operators, such as algebraic product Fuzzy Algebraic Product Operator - FAPO (minimizes the results), algebraic sum - Fuzzy Algebraic Sum Operator - FASO (maximizes the results), and fuzzy gamma operator - FGO (balances the results). Details regarding these operators are provided in Zimmermann (1985); An et al. (1991); Bonham-Carter (1994); Eddy et al. (2006); Nykänen et al. (2008) and Carrino et al. (2011).

Regarding the operator "fuzzy gamma", which was used to create the final predictability maps, Bonham-Carter (1994) showed that $\gamma$ values between 0 and 0.35 are "decreasive", i.e., always lower or equal to the lowest input fuzzy member, whereas values between 0.8 and 1 are "increasive" (i.e., the output value is larger or equal to the largest input fuzzy member) and values between 0.35 and 0.8 are neither

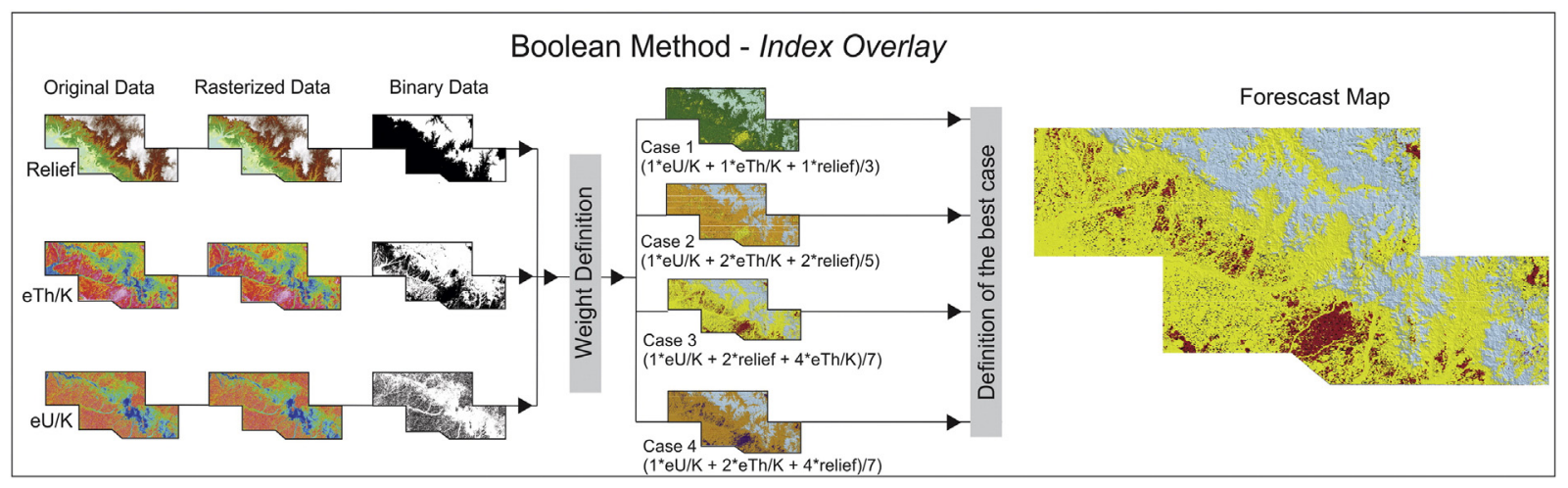

Fig. 1. Flowchart of procedures performed for the Boolean logic. 
"increasive" nor "decreasive". In this last case, the values always lie within the range of input values.

In practice, the larger "fuzzy gamma" operators tend to restrict less the interest areas, whereas the smaller "fuzzy gamma" operators tend to restrict more. The fuzzy result obtained in this work considered the data equal to the average plus one and a half times the standard deviation as significant, and the fuzzy result was compared with the soil map and the Boolean model.

Different values for gamma between 0.1 and 0.9 were evaluated to clarify the application of the fuzzy method and determine the best gamma operator. The final choice of the best value was based on a comparison with the field data and Boolean results. The set of procedures performed to create the predictability map in the fuzzy technique used the gamma operators $\gamma=0.7$ and $\gamma=0.3$ (Fig. 2).

\subsection{Regional geologic and geomorphologic context}

The research area is located on the western portion of the Amazon craton and comprises the geochronological provinces of Sunsás and Rondônia-Juruena (Fig. 3). Within this context, there is the Alto Guaporé Belt, established during the evolution of the Rondoniano-San Ignácio Orogene (1.47-1.32 Ga) (Rizzotto, 2010). Regarding evolution, the geology is diverse, with ages from Mesoproterozoic up to the current period.

The Mesoproterozoic is represented by para-derived, granitoids, and mafic and ultramafic rocks (Rizzotto, 2010).The Paleozoic to Mesozoic units are represented by sandstones, conglomerates, and siltites of the Parecis Basin. The units associated with the Cenozoic are fluvial and swampy clayey-sandy as well as gravel deposits and lateritic crusts. The lateritic crusts are mainly composed of ferruginous crusts and colluviums originating from its dismantling process, covered by up to $1 \mathrm{~m}$ of soil (Quadros and Rizzotto, 2007).

The study area has altitudes ranging between 149 and $627 \mathrm{~m}$. There are three major relief units: i) the Guaporé Depression, generally associated with a pediplained surface with elevations lower than $300 \mathrm{~m}$ (Cenozoic); ii) the desiccated unit in the Parecis plateau, related to the Parecis Basin (Mesozoic), with altitudes between 500 and $627 \mathrm{~m}$; and iii) the intermediate zone with altitudes between 301 and $499 \mathrm{~m}$, where there are sporadic Mesoproterozoic inselbergs and tors (Fig. 3). These domains are correlated to the inferior planation, topo II planation, and intermediate planation, surfaces of Kux et al. (1979), respectively. The lateritic crusts support the majority of the Guaporé Depression and the Parecis plateau.

\subsubsection{Lateritization on the study area}

Three types of profiles were identified in the study area (Fig. 4):

i) The tabular surfaces developed over the quartz and arkose sandstones of the Utiariti formation of the Parecis Basin (at altitudes above $500 \mathrm{~m}$, in the east-central portion of the study area). The profile has brown to yellow cellular lateritic crust with a thickness of up to $2 \mathrm{~m}$ that is mainly composed of goethite, grains, and gravels of quartz covered by red oxisol. There is occasionally superficial colluvium with lateritic fragments and spherulites embedded in red sandy to sandy-silty kaolinite matrix or a dismantled lateritic crust between the lateritic crust and oxisol (Fig. 4A, B, and G).

ii) The desiccated surfaces developed over the para-derived rocks and granitoids and, to a lesser extent, mafic-ultramafic rocks (at altitudes between 301 and $499 \mathrm{~m}$, in the northwestern to southwestern portion of the study area). The profiles are truncated and are formed by soft mottled or saprolite horizons covered by colluvium and, to a lesser extent, red oxisol. They are composed of kaolinite, quartz grains, and low content of ferruginous concretions. At three sites, there are blocks of ferruginous pisoliths, nodular and vermiform lateritic crusts with diameters of $20-40 \mathrm{~cm}$ embedded in red sandy to sandy-silty kaolinite matrix.

iii) The surfaces developed over the para-derivades, granitoids, and subordinate mafic-ultramafic rocks (at altitudes below $300 \mathrm{~m}$, on plain and low relief with some flooded areas and sporadic inselbergs and tors). The profiles have ochre to red soft vermiform lateritic crusts with thicknesses of 1-2 m. They are mainly composed of goethite, kaolinite, and quartz, with lower contents of hematite and rare gibbsite, and are covered by red oxisols. As in profile type i, there is occasionally superficial colluvium with lateritic fragments and spherulites embedded in red sandy to sandy-silty kaolinite matrix or a dismantled lateritic crust between the lateritic crust and oxisol (Fig. 4E, F, and G).

\section{Results}

\subsection{Integration of airborne gamma-ray spectrometry and altimetry images}

The ternary composition ( $\mathrm{K}$, eTh, and eU) shows several areas with gamma spectrometric signatures related to high values of eTh, low values of $\mathrm{K}$ and low to intermediate values of eU that could be credited to the presence of lateritic crusts and weathering materials according to Dickson and Scott (1997); Dauth (1997); Carrino et al. (2011); Minty (2011) and Wilford (2012). However, the airborne geophysical products alone were not sufficient to make a complete discrimination, as some areas mapped as lateritic crusts present inconclusive responses in the three channels (eU, eTh, and $\mathrm{K}$ ). In the northeast, southwest and northwest, there are several sectors that highlight the predominance of eTh. The spectrometric response patterns (eTh, eU and $\mathrm{K}$ ) are observed in profile $\mathrm{A}^{\prime}$ (Fig. 5), as is the outcrop location of the points described previously (Fig. 4). There is a relative decrease in $\mathrm{K}$ and increase in eU and eTh in areas where lateritic crusts are mapped. Table 1 shows a statistical summary of the $\mathrm{eTh} / \mathrm{K}$ eU/K, and relief images.

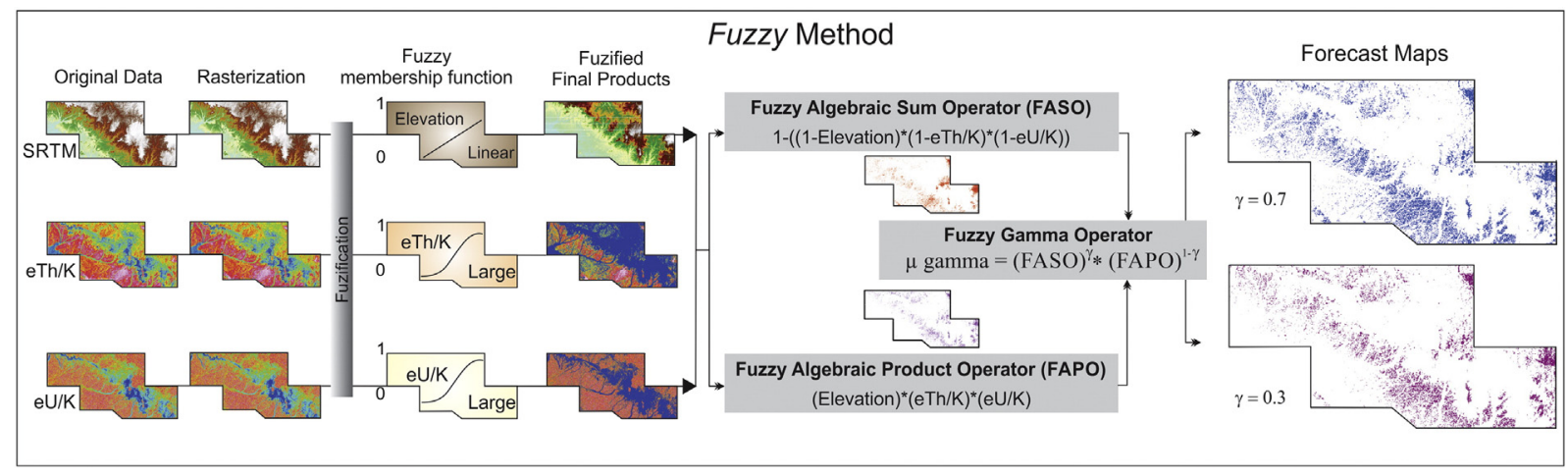

Fig. 2. Flowchart of the procedures performed for the fuzzy logic. 


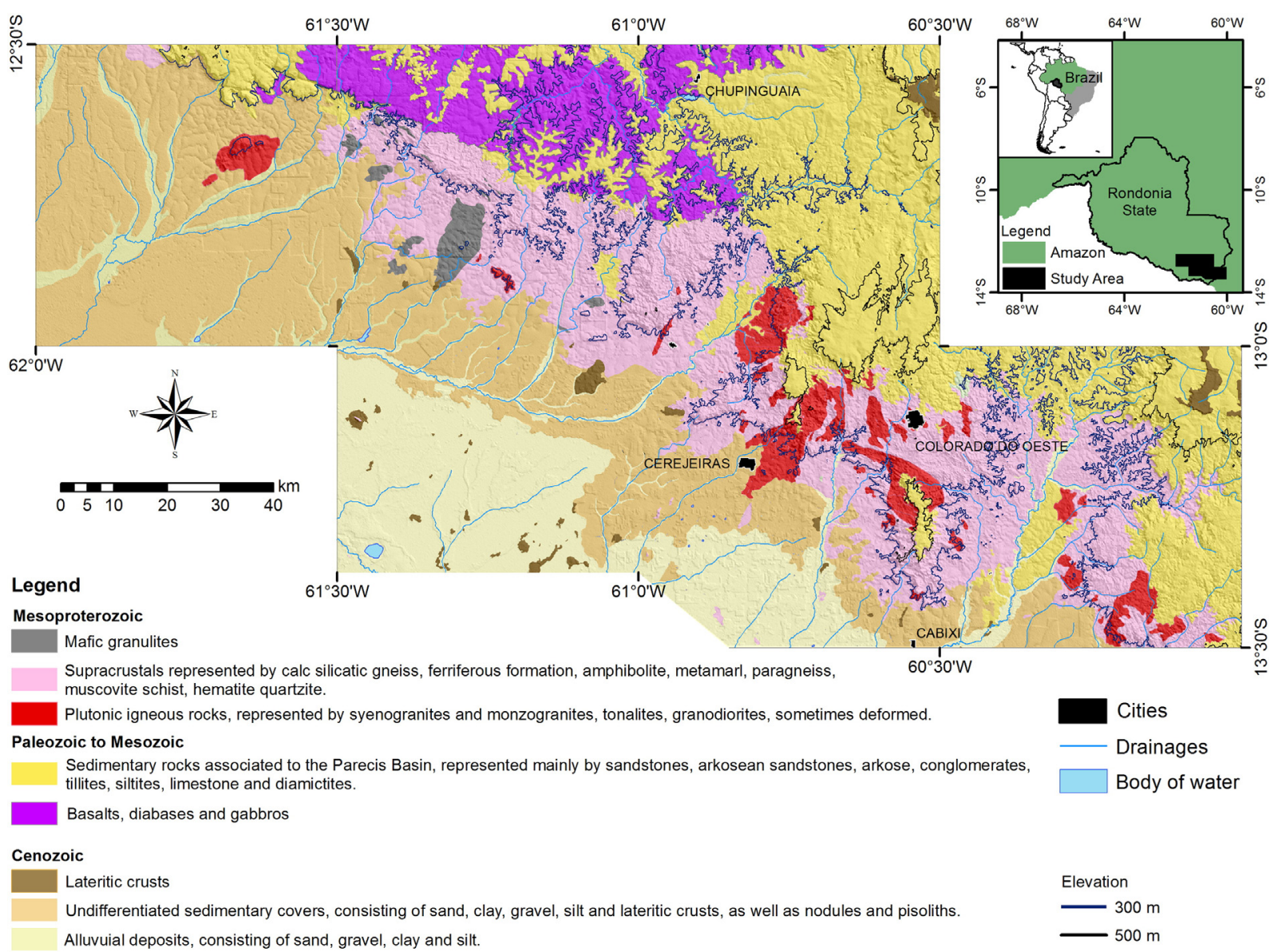

Fig. 3. Simplified geologic map, modified from Quadros and Rizzotto (2007); Rizzotto (2010), (2012a, b).

A previous evaluation of the SRTM image (relief) and the ratios eTh/ $\mathrm{K}$ and $\mathrm{eU} / \mathrm{K}$ using field data was performed to integrate the products and understand the response pattern associated with lateritic crusts. The ternary composition of eTh/K, SRTM (relief), and eU/K in the RGB channels showed a higher efficiency in the previous identification of lateritic crusts and indicated several areas with high and low elevations (often explained by tectonics and/or geomorphology; Taylor and Eggleton, 2001; Taylor, 2008), simultaneously associated with high values of eTh/K and eU/K (Fig. 6).

\subsection{Spatial modeling and correlation with lateritization}

\subsubsection{Boolean logic}

The four cases presented above were analyzed to choose the optimal weight combination and obtain the best discrimination of areas with lateritic crusts and dismantling products.

In case 1 , in which all of the variables have the same importance level (all weights equal to 1 ), some combinations that are likely to represent lateritic crust ( $\mathrm{eTh} / \mathrm{K}+$ relief) are mixed with combinations that are unlikely to represent lateritic crusts (eU/K + relief), which hinders the discrimination of potential areas. The combination of all variables, with a score of 1 , represents areas with the highest probability of lateritic crust occurrence, covering $1.30 \%$ of the area.

In case 2 , in which the ratio $\mathrm{eU} / \mathrm{K}$ has a weight of 1 due to the higher mobility of $U$ compared with Th and the other variables have weights of 2 , there is an increase in the percentage of the potential areas considered favorable (7.84\%). However, there is still a mixture of likely and unlikely combinations, as in case 1 . This condition is undesirable for the evaluation of the model, as it does not completely discriminate the potential areas and does not allow for a thorough interpretation and correlation with geologic, pedologic, and geomorphologic aspects.

In case 3 , all variables have different weights arranged in a geometric progression of common ratio $2\left(A_{n}=2^{n-1}\right):(1 * \mathrm{eU} / \mathrm{K}+2 *$ relief + $4 * \mathrm{eTh} / \mathrm{K}) / 7$, which allows for the visual discrimination of all possible combinations of variables. In this case, the ratio $\mathrm{eTh} / \mathrm{K}$ was considered the most significant variable because it represents the enrichment of Th in relation to $\mathrm{K}$, which is an important condition in a weathering context. The final map highlights 8 scores (Fig. 7). The combinations are redistributed, as each score contains a single combination instead of a mixture of combinations, as observed in the previous cases. This enables a better understanding of the variables involved. The results considered as favorable or extremely favorable represent $7.84 \%$ of the area and yield a kappa value of 0.87 .

Case 4 presents the same results as case 3 in terms of potential areas (7.84\%) and the kappa value (0.87); however, the combination of variables is rearranged. All of the results regarding the Boolean cases are shown in Table 2, which provides the formulae, reasons for the weights assigned, the different combinations, the favorability level, and the confusion matrix elements and respective kappa values for each case.

\subsubsection{Fuzzy logic}

In the fuzzy technique, the algebraic sum and product as well as the fuzzy gamma operator were used. The algebraic sum and product present different responses in relation to the delimitation of potential areas. In the case of the algebraic sum (FASO), the areas with altitudes above $500 \mathrm{~m}$ are overestimated, whereas those located below $300 \mathrm{~m}$ are observed less frequently. In the algebraic product (FAPO), the areas predicted by the algebraic sum, especially those above $500 \mathrm{~m}$, are redistributed. The areas highlighted as the most favorable by FASO 

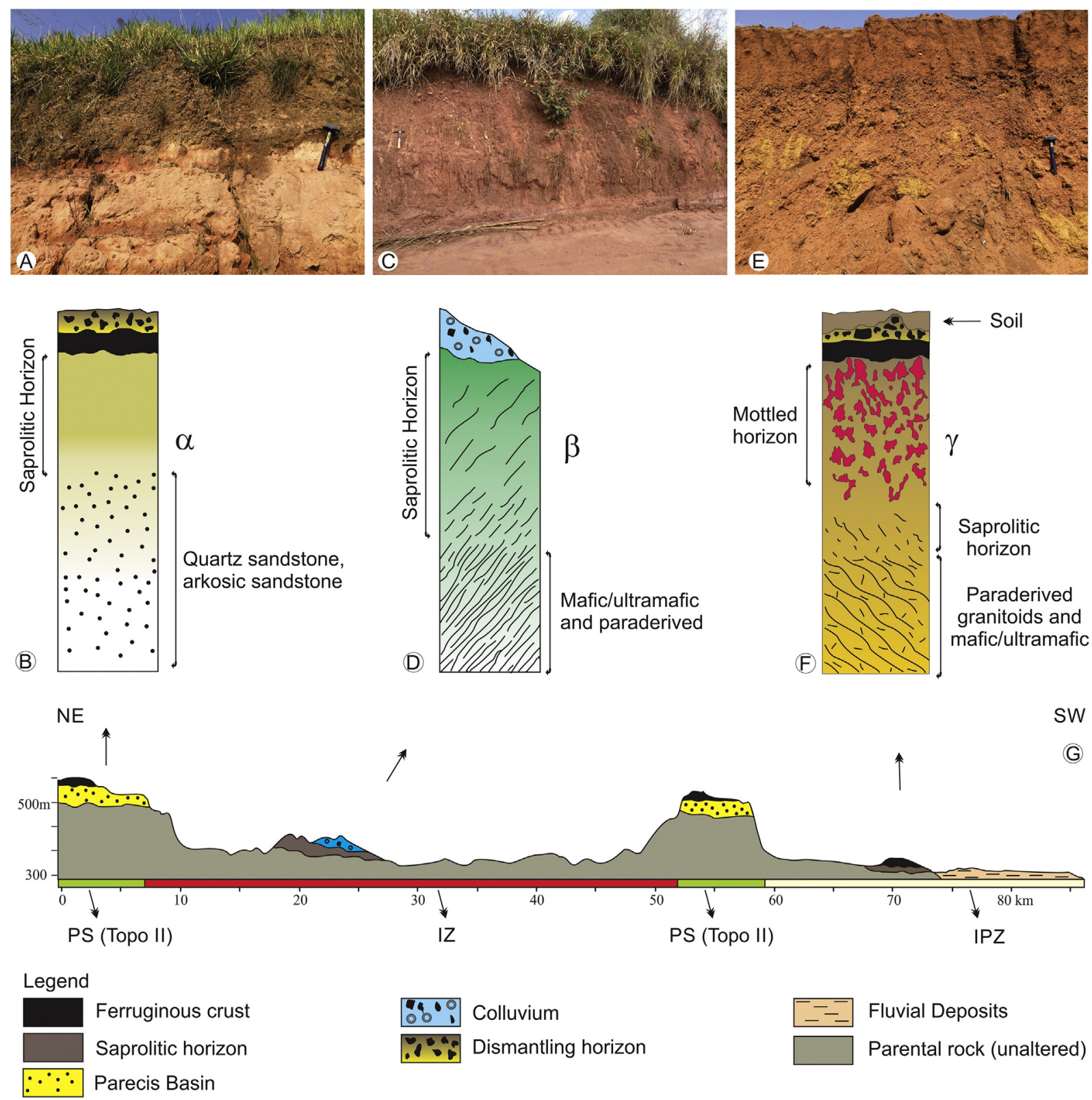

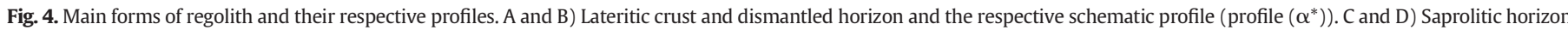

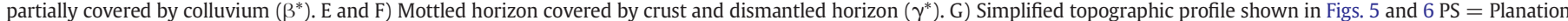
Surface; IPZ = Inferior Planation Zone; IZ = Intermediate Zone. *The Greek letters refer to profiles related to actual lateritic crust sites in the field (Figs. 5 and 6 ).

and FAPO represent $6.07 \%$ and $4.37 \%$ of the area, respectively. The information related to the fuzzy intervals, the areas and the respective favorability levels, as well as information regarding the confusion matrix elements and kappa value associated for each operation, are provided in Table 3.

The fuzzy gamma operator (FGO) was used to balance the results obtained in FASO and FAPO. The results for fuzzy gamma values of 0.3 and 0.7 , which illustrate the most pessimistic and optimistic results, respectively (Table 3, Figs. 8 and 9), approximated the largest proportion of the areas mapped as undifferentiated sedimentary covers and lateritic crusts, as well as oxisols. The similarity between the maps is evident; however, gamma values higher than 0.7 or lower than 0.3 increase and restrict the areas causing a decrease in kappa, respectively. The final maps (FGO 0.7 and FGO 0.3, Figs. 8 and 9) show new areas not represented by the FASO or FAPO. These new areas are due to the transformation suffered by the input data when the fuzzy gamma operator is applied, i.e., there is a restaggering of the original data matrix. The final areas obtained in both cases ( 0.3 and 0.7$)$ refer to values higher than the average plus one and a half times the standard deviation and represent the products with the highest reliability.

\section{Discussion and model validation}

The results obtained considered the gamma spectrometric responses for depths of up to $45 \mathrm{~cm}$ and highlighted the potential areas for the occurrence of lateritic crust or dismantling products on the surface.

Minty (1997) considered that the intensity of the gamma rays can increase or decrease according to the humidity conditions on the surface. A $20 \%$ increase in the humidity of the ground results in a $20 \%$ reduction in the amount of rays emitted on the ground surface. Vegetal tissues contain insignificant traces of $T h$ and $U$ and thus have an insignificant effect on the gamma-ray response; however, they can cause attenuation of the signal and should be considered in the gamma spectrometric 


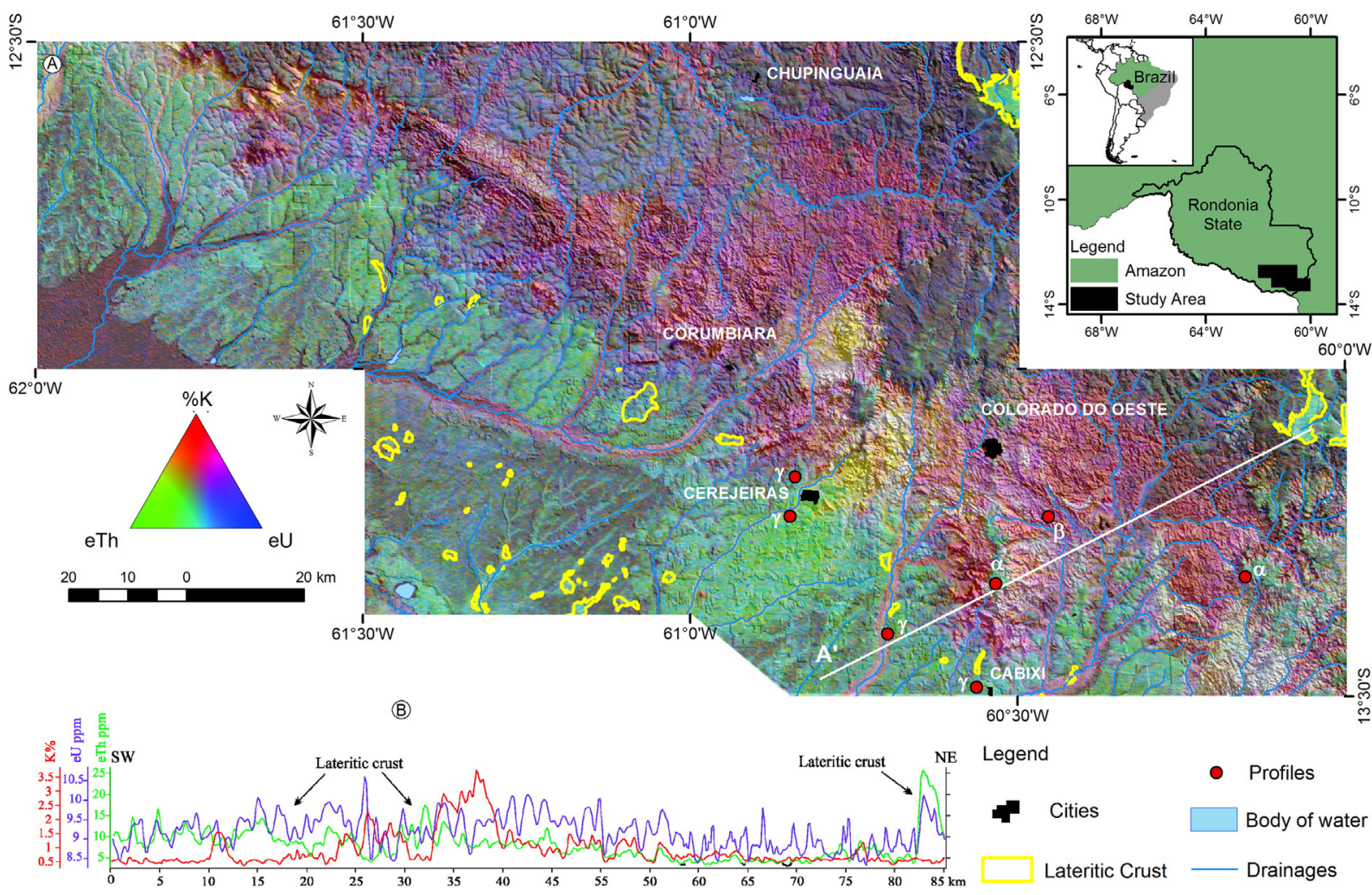

Fig. 5. Ternary map of K, eTh and eU on the RGB channels and relief image.

interpretation (Wilford et al., 1997). Furthermore, Kogan et al. (1969) showed that the absorption of $\mathrm{K}$ by plants can constitute up to $15 \%$ of the signal that reaches the aircraft. Although the study region is located within the official limits of the Amazon, it has a low vegetal cover compared with the remainder of the Amazon due to deforestation.

The airborne geophysical data were acquired during the drier season, providing the best possible conditions for data collection. Minty (2011) stated that when gamma spectrometric ratios are used, there is a tendency to remove environmental artifacts in the data due to soil moisture, vegetation, or the effect of non-radioactive overburden. In any case, the final results showed good correlation between the proposed models and field data.

Regarding the cases for weight determination for the IOM (Boolean method), cases 1 and 2 are not ideal combinations of weights, as they exhibit classes (scores) in which there is a mixture of variables considered favorable and not favorable, which prevents a complete evaluation of the models. Cases 3 and 4 are equivalent, only showing a rearrangement in the order of classes. They can be considered the best representation for the identification of lateritic crusts, as they allow the individualization of all possible variable combinations, which favors the evaluation and full judgment of the model.

The integration of the images in the Boolean logic exhibits a strong correlation between relief and the values of eTh/K in several sites, especially those over $500 \mathrm{~m}$ that were classified as extremely favorable. This identification was enabled using weights of 1,2 , and 4 on the eU/K, relief, and eTh/K images, respectively. The areas with elevations lower

Table 1

Statistical summary of the $\mathrm{eTh} / \mathrm{K}, \mathrm{eU} / \mathrm{K}$, and relief airborne geophysical products.

\begin{tabular}{lcccrc}
\hline Product & Min & Max & Sum & Mean & $\begin{array}{c}\text { Standard } \\
\text { deviation }\end{array}$ \\
\hline eTh/K & 0.38 & 107.73 & $12,463,240.24$ & 11.36 & 7.06 \\
eU/K & 1.3 & 48.7 & $15,217,718.95$ & 13.87 & 4.54 \\
Relief & 149 & 627 & $582,263,520$ & 283.51 & 98.25 \\
\hline
\end{tabular}

than $300 \mathrm{~m}$ also have high values of eTh/K and thus a direct correlation with lateritic crusts or dismantling products. In general, these areas strongly overlap with the geologic units called undifferentiated sedimentary covers and also indicate new potential areas for the occurrence of lateritic crusts.

In areas classified as not favorable, the crusts were either not found or registered as restrict occurrences. The sites considered favorable or extremely favorable (i.e., influenced by relief, eTh/K, and eU/K) represent approximately $7.84 \%$ of the area and tend to show lateritic crusts in accordance with field data $(\kappa=0.87)$. Therefore, there is a good correlation between the favorability predicted and the presence of crusts in the study area, which confirms the efficiency of the Boolean model proposed.

This model is considered simple, and when combined with weights (IOM), it allows for the separation of the results in terms of scores that vary from 0 to 1 . In this sense, the application of weights arranged in a geometric progression allows for not only the discrimination of the classes but also the visualization of the areas related to the influence of each variable or its possible combinations individually in logical order on the final map.

The other combinations of weights showed similar results as those observed in cases 1 and 2 (class overlapping) or cases 3 and 4 (total discrimination of classes). Therefore, it is important to guarantee that all combinations are represented visually through the choice of weights that result in distinct classes and representative of all possible combinations.

The fuzzy method FASO tends to overestimate the potential areas with altitudes over $500 \mathrm{~m}$, whereas FAPO tends to overestimate areas below $300 \mathrm{~m}$, although it shows potential sectors in the intermediate zone (altitudes of 301 to $499 \mathrm{~m}$ ). Therefore, none of these methods represent the real data satisfactorily. The fuzzy gamma operator result is sufficiently correlated with the occurrence of lateritic crusts. A fuzzy gamma operator of 0.7 highlights areas not identified on the Boolean map, especially on the southeast and north central portions of the area, with excellent correlation, and it represents the most optimistic option for the occurrence of lateritic crusts and dismantling products. 


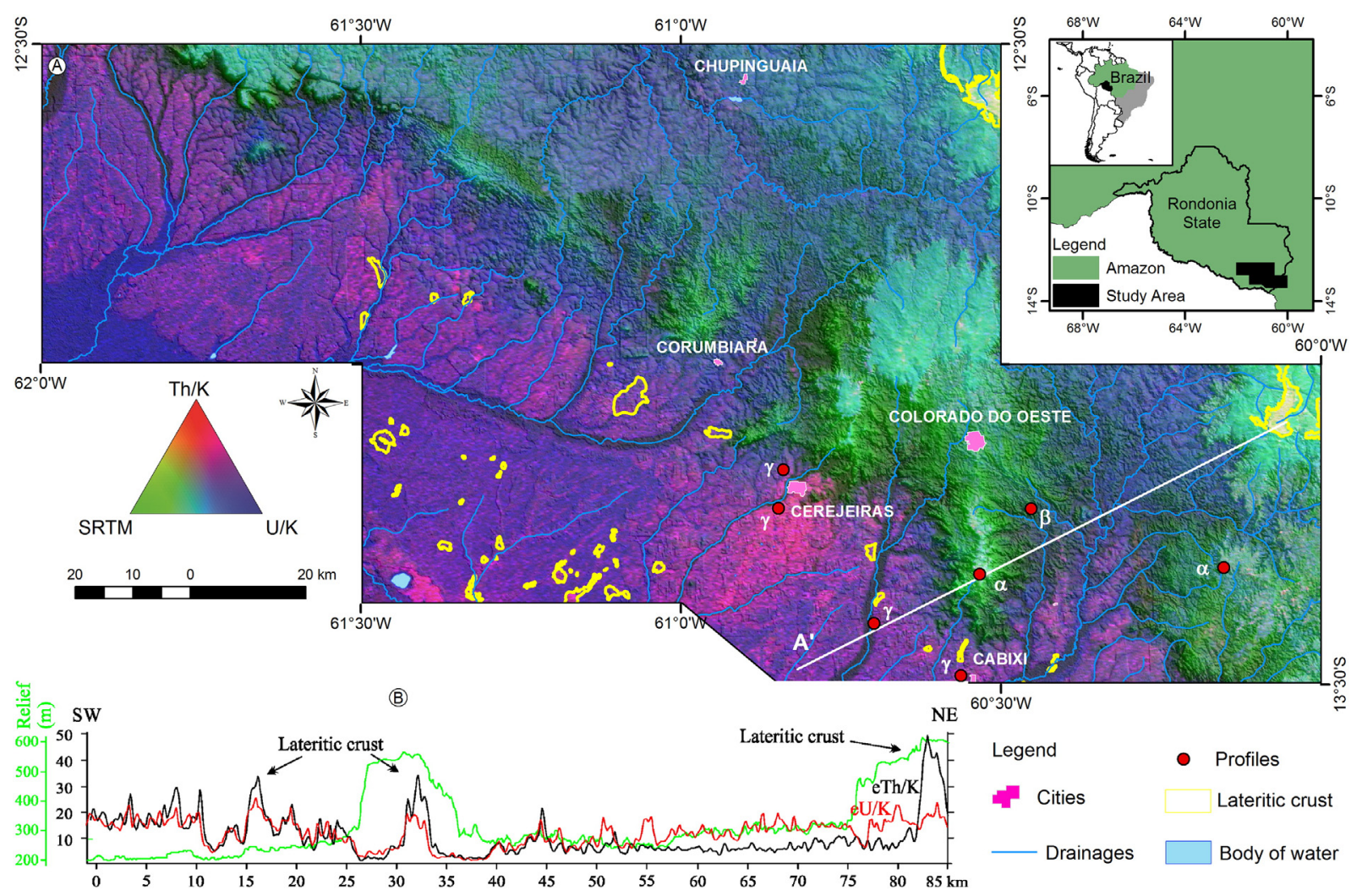

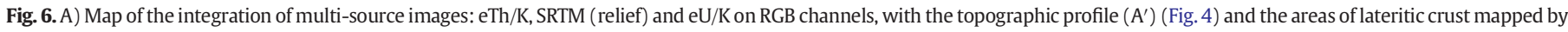

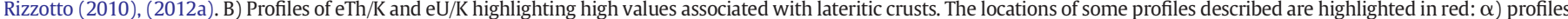

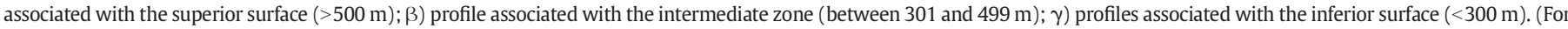
interpretation of the references to color in this figure legend, the reader is referred to the web version of this article.)
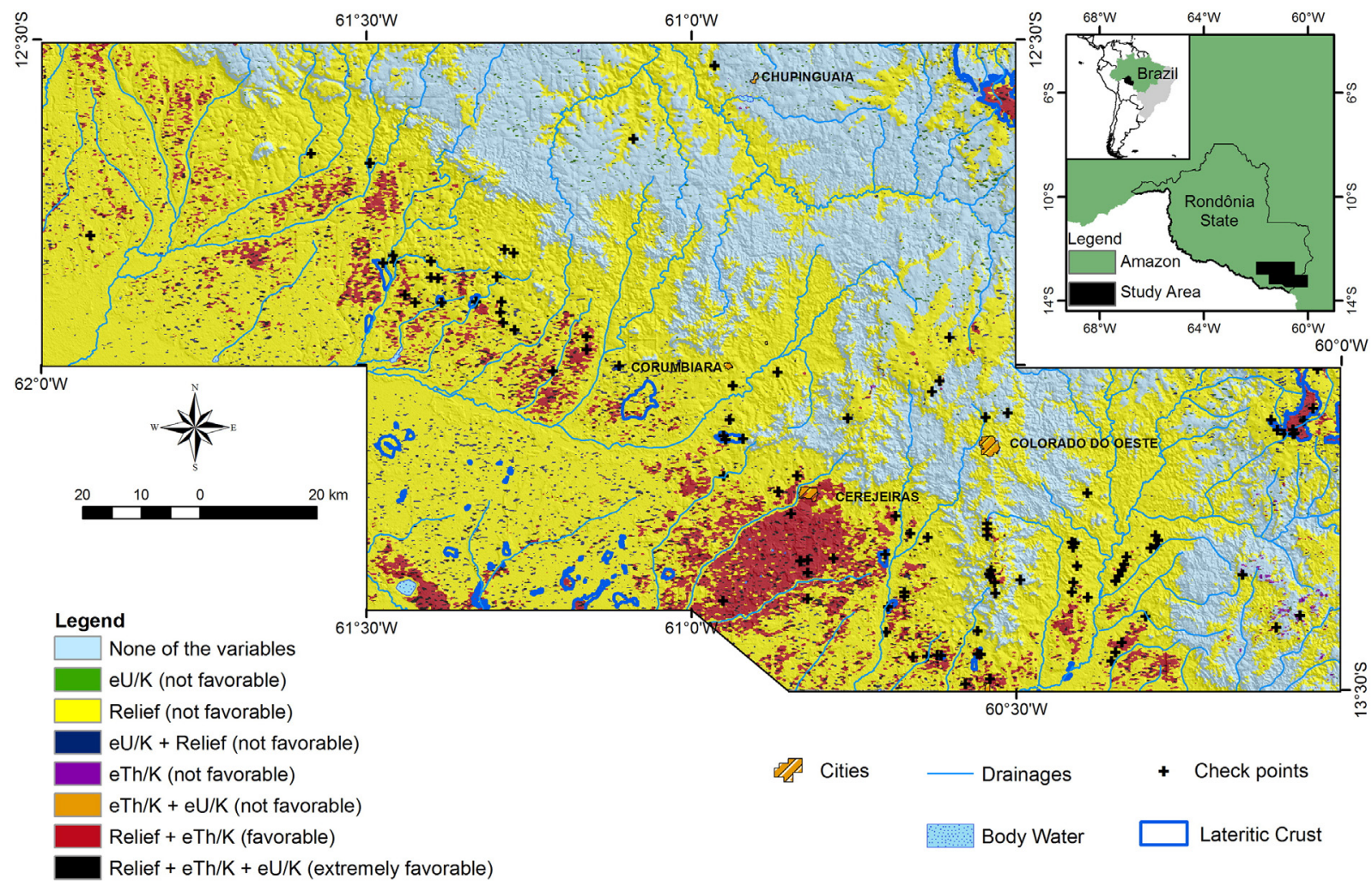

Fig. 7. Predictability map of lateritic crust occurrence based on Boolean logic - IOM Case 3. 
Table 2

Results of the Boolean logic.

\begin{tabular}{|c|c|c|c|c|c|c|c|c|}
\hline Case & Formulae & Reasons & Products within each score & Scores & $\begin{array}{l}\text { Area } \\
\%\end{array}$ & Favorability & $\begin{array}{l}\text { Confusion } \\
\text { matrix* }^{*}\end{array}$ & $\kappa$ \\
\hline 1 & $(1 * \mathrm{eU} / \mathrm{K}+1 * \mathrm{eTh} / \mathrm{K}+1 *$ relief $) / 3$ & $\begin{array}{l}\text { All variables have the same } \\
\text { importance }\end{array}$ & $\begin{array}{l}\text { NONE } \\
\text { eU/K, Relief OR eTh/K } \\
\text { Relief + eU/K, eTh/K + eU/K OR } \\
\text { Relief + eTh/K } \\
\text { eU/K + Relief + eTh/K }\end{array}$ & $\begin{array}{l}0 \\
0.33 \\
0.67 \\
1\end{array}$ & $\begin{array}{l}26.93 \\
63.90 \\
7.86 \\
1.30\end{array}$ & $\begin{array}{l}\text { Extremely not favorable } \\
\text { Not favorable } \\
\text { Not favorable } \\
\text { Extremely favorable }\end{array}$ & $19-86-730-40$ & 0.84 \\
\hline 2 & $(1 * \mathrm{eU} / \mathrm{K}+2 * \mathrm{eTh} / \mathrm{K}+2 *$ relief $) / 5$ & $\begin{array}{l}\text { The ratio } \mathrm{eTh} / \mathrm{K} \text { and relief are more } \\
\text { relevant than the ratio eU/K due to } \\
\text { the higher mobility of uranium } \\
\text { compared with thorium }\end{array}$ & $\begin{array}{l}\text { NONE } \\
\text { eU/K } \\
\text { Relief OR eTh/K } \\
\text { Relief + eU/K OR eTh/K + eU/K } \\
\text { eTh/K + Relief } \\
\text { eTh/K + Relief + eU/K }\end{array}$ & $\begin{array}{l}0 \\
0.2 \\
0.4 \\
0.6 \\
0.8 \\
1\end{array}$ & $\begin{array}{l}26.93 \\
0.33 \\
63.57 \\
1.32 \\
6.54 \\
1.30\end{array}$ & $\begin{array}{l}\text { Extremely not favorable } \\
\text { Not favorable } \\
\text { Not favorable } \\
\text { Not favorable } \\
\text { Favorable } \\
\text { Extremely favorable }\end{array}$ & $52-53-715-55$ & 0.87 \\
\hline 3 & $(1 * \mathrm{eU} / \mathrm{K}+2 *$ relief $+4 * \mathrm{eTh} / \mathrm{K}) / 7$ & $\begin{array}{l}\text { The ratio eTh/K is more relevant } \\
\text { because it emphasizes areas with } \\
\text { higher enrichment of thorium } \\
\text { related to potassium, which is an } \\
\text { important condition in a } \\
\text { weathering context }\end{array}$ & $\begin{array}{l}\text { NONE } \\
\text { eU/K } \\
\text { Relief } \\
\text { eU/K + Relief } \\
\text { eTh/K } \\
\text { eTh/K + eU/K } \\
\text { eTh/K + Relief } \\
\text { eTh/K + Relief + eU/K }\end{array}$ & $\begin{array}{l}0 \\
0.14 \\
0.29 \\
0.43 \\
0.57 \\
0.71 \\
0.86 \\
1\end{array}$ & $\begin{array}{l}26.93 \\
0.33 \\
63.49 \\
1.30 \\
0.08 \\
0.02 \\
6.54 \\
1.30\end{array}$ & $\begin{array}{l}\text { Extremely not favorable } \\
\text { Not favorable } \\
\text { Not favorable } \\
\text { Not favorable } \\
\text { Not favorable } \\
\text { Not favorable } \\
\text { Favorable } \\
\text { Extremely favorable }\end{array}$ & $64-41-710-60$ & 0.87 \\
\hline 4 & $(1 * \mathrm{eU} / \mathrm{K}+2 * \mathrm{eTh} / \mathrm{K}+4 *$ relief $) / 7$ & $\begin{array}{l}\text { The relief has more influence } \\
\text { because it has a close relation with } \\
\text { the genesis and development of } \\
\text { lateritic crusts, and it also presents a } \\
\text { wide continuity and forms vast } \\
\text { regional planation surfaces }\end{array}$ & $\begin{array}{l}\text { NONE } \\
\text { eU/K } \\
\text { eTh/K } \\
\text { eU/K + eTh/K } \\
\text { Relief } \\
\text { Relief + eU/K } \\
\text { eTh/K + Relief } \\
\text { eTh/K + Relief + eU/K }\end{array}$ & $\begin{array}{l}0 \\
0.14 \\
0.29 \\
0.43 \\
0.57 \\
0.71 \\
0.86 \\
1\end{array}$ & $\begin{array}{l}26.93 \\
0.33 \\
63.49 \\
1.30 \\
0.08 \\
0.02 \\
6.54 \\
1.30\end{array}$ & $\begin{array}{l}\text { Extremely not favorable } \\
\text { Not favorable } \\
\text { Not favorable } \\
\text { Not favorable } \\
\text { Not favorable } \\
\text { Not favorable } \\
\text { Favorable } \\
\text { Extremely favorable }\end{array}$ & $64-41-710-60$ & 0.87 \\
\hline
\end{tabular}

* Respective values for laterites predicted as laterites, laterites predicted as non-laterites, non-laterites predicted as non-laterites and non-laterites predicted as laterites.

A gamma operator of 0.3 , although highly similar to 0.7 , is slightly more restrictive in some areas. However, it also delimits some favorable sectors on the southeast portion of the area that were not highlighted in the Boolean method. This value represents the most pessimistic option for the prediction of crust occurrence. Thereby, the "fuzzy gamma" method tends to balance the influences of the FASO and FAPO and consequently the input variables. In particular, the areas with intermediate altitudes (between 301 and $499 \mathrm{~m}$ ) were not highlighted in the Boolean model, as they were not considered in the relief input binary map. This fact may be the reason for the slightly lower values of kappa observed in the Boolean cases compared with the FGO with a gamma value of 0.7, which considers intermediate input values in all of the products, including altimetric data.

In general, the fuzzy method allows for the generation of images with favorable areas and high correlation, but it is not able to discriminate the influence of the input products individually (relief, eTh/K and $\mathrm{eU} / \mathrm{K})$, i.e., it is not possible to visually identify the influence of each variable. In contrast, the Boolean model generates favorable areas with only good correlation, but it enables the individualization of the influence of the input images (eTh/K, relief, eU/K), consequently allowing for an analysis of each variable involved in the construction of the model.

Table 3

Results of the fuzzy logic and the respective favorability classes.

\begin{tabular}{|c|c|c|c|c|c|c|}
\hline Case & Formulae & Fuzzy intervals & Areas \% & Favorability & Confusion matrix* & $\kappa$ \\
\hline \multirow[t]{5}{*}{ FASO } & \multirow[t]{5}{*}{$1-((1-E l e v a t i o n) *(1-e T h / K) *(1-e U / K))$} & $0.012-0.256$ & 15.39 & Not favorable & \multirow[t]{5}{*}{$48-57-715-55$} & \multirow[t]{5}{*}{0.86} \\
\hline & & $0.256-0.43$ & 22.21 & Not favorable & & \\
\hline & & $0.43-0.597$ & 21.88 & Not favorable & & \\
\hline & & $0.597-0.87$ & 34.46 & Not favorable & & \\
\hline & & $0.87-1$ & 6.07 & Extremely favorable & & \\
\hline \multirow[t]{5}{*}{ FAPO } & \multirow[t]{5}{*}{$($ Elevation $) *(\mathrm{eTh} / \mathrm{K}) *(\mathrm{eU} / \mathrm{K})$} & $0-0.013$ & 78.59 & Not favorable & \multirow[t]{5}{*}{$88-17-680-90$} & \multirow[t]{5}{*}{0.86} \\
\hline & & $0.013-0.55$ & 17.04 & Not favorable & & \\
\hline & & $0.55-0.13$ & 3.28 & Extremely favorable & & \\
\hline & & $0.13-0.27$ & 0.81 & Extremely favorable & & \\
\hline & & $0.27-0.69$ & 0.29 & Extremely favorable & & \\
\hline \multirow[t]{5}{*}{$\gamma=0.7$} & \multirow[t]{5}{*}{$\mu$ Gamma $=(\mu \text { FASO })^{0,7} *(\mu \text { FAPO })^{1-0.7}$} & $0-0.073$ & 65.99 & Not favorable & \multirow[t]{5}{*}{$89-16-718-52$} & \multirow[t]{5}{*}{0.91} \\
\hline & & $0.073-0.20$ & 11.12 & Not favorable & & \\
\hline & & $0.20-0.3$ & 12.18 & Not favorable & & \\
\hline & & $0.3-0.48$ & 9.31 & Extremely favorable & & \\
\hline & & $0.48-0.89$ & 1.40 & Extremely favorable & & \\
\hline \multirow[t]{5}{*}{$\gamma=0.3$} & \multirow[t]{5}{*}{$\mu$ Gamma $=(\mu \text { FASO })^{0,3} *(\mu \text { FAPO })^{1-0.3}$} & $0-0.024$ & 71.42 & Not favorable & \multirow[t]{5}{*}{$83-22-719-51$} & \multirow[t]{5}{*}{0.90} \\
\hline & & $0.024-0.079$ & 17.35 & Not favorable & & \\
\hline & & $0.079-0.1$ & 3.90 & Not favorable & & \\
\hline & & $0.1-0.325$ & 6.78 & Extremely favorable & & \\
\hline & & $0.325-0.77$ & 0.55 & Extremely favorable & & \\
\hline
\end{tabular}

* Respective values for laterites predicted as laterites, laterites predicted as non-laterites, non-laterites predicted as non-laterites and non-laterites predicted as laterites. 


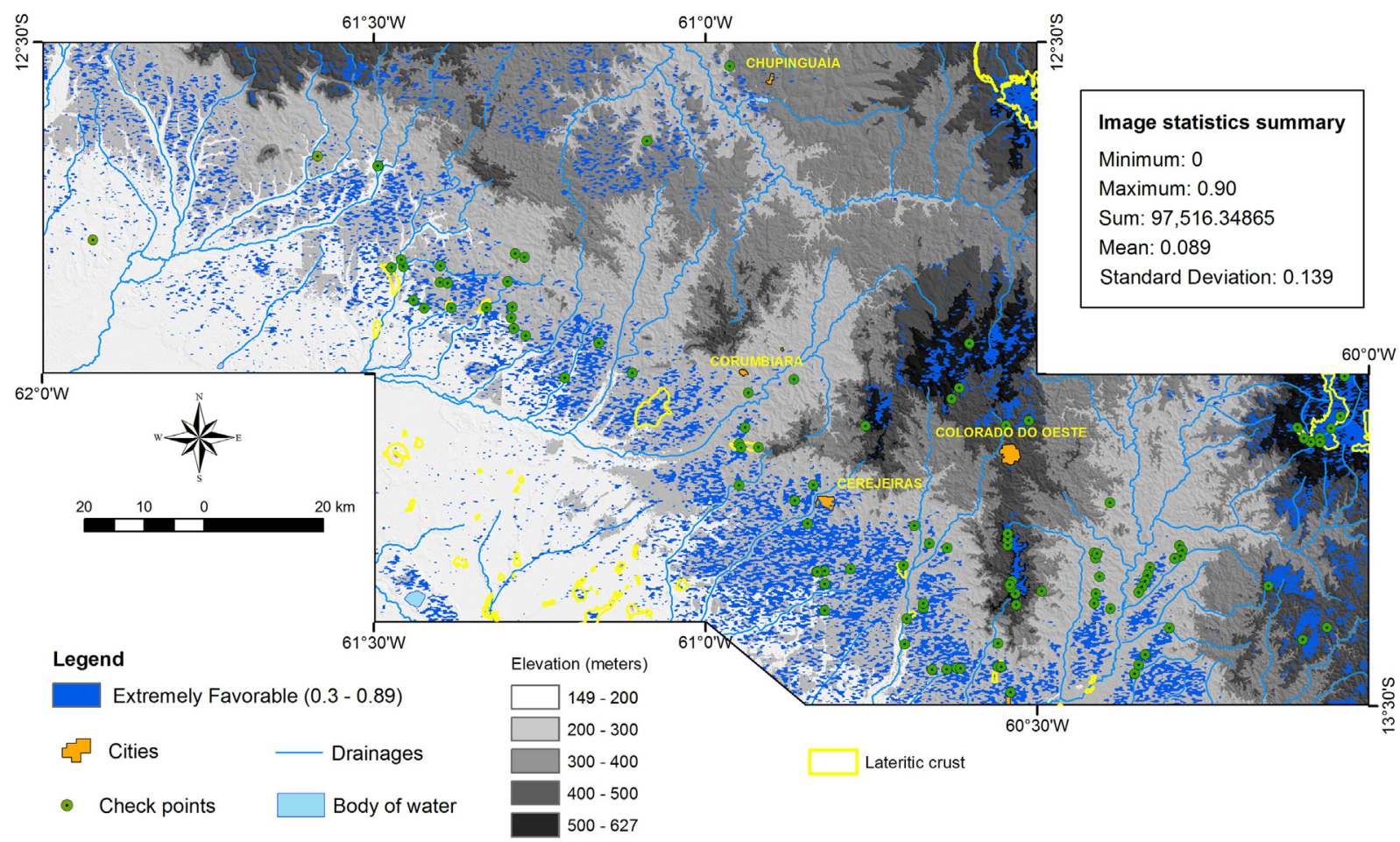

Fig. 8. Predictability map of the occurrence of lateritic crust based on the fuzzy gamma operator $(\gamma=0.7)$.

The correlation between the FGO 0.7 model and the map of soils is significant (Fig. 10) and even stronger when considering areas mapped as lateritic crusts and checkpoints. The overlap is substantial when compared with the geologic map, especially with the units referred to as undifferentiated sedimentary covers and with crusts mapped by previous works.

An aspect to be considered is the spatial resolution of the images and the expectation of the results. The images have pixels with $125 \mathrm{~m}$ (airborne geophysics) and $30 \mathrm{~m}$ (SRTM), which limits the study to scales lower than 1:100,000. Therefore, the extension and the mode of occurrence of the crusts (e.g., blocks, boulders, pisoliths) must be considered.

The model developed highlights not only areas with lateritic crust (blocks and boulders) but also dismantling products (crust fragments, ferruginous concretions), with oxisols occasionally covering these ferruginous products. Although there is an excellent correlation with the field data, the models used were not able to discriminate or

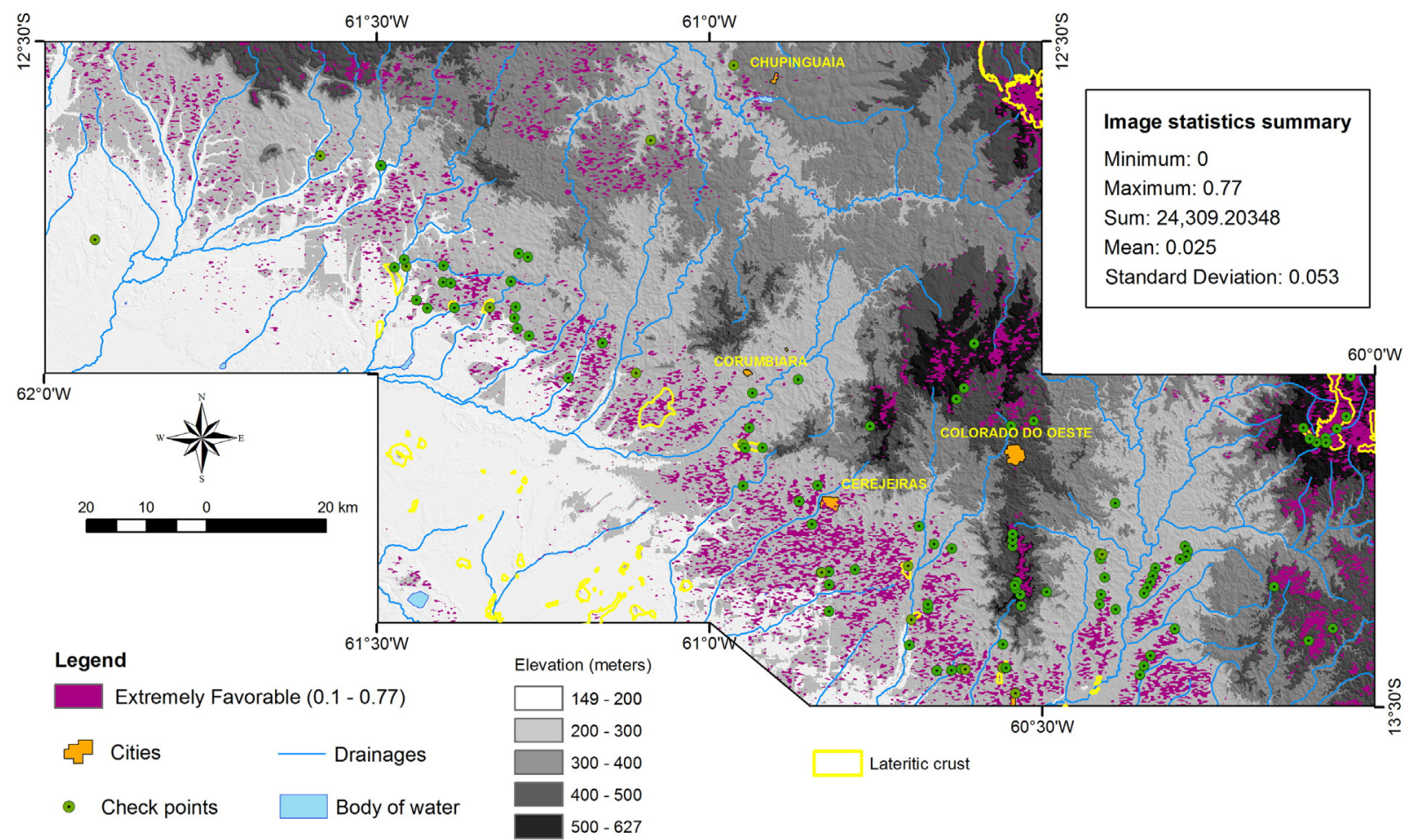

Fig. 9. Predictability map of the occurrence of lateritic crust based on the fuzzy gamma operator $(\gamma=0.3)$. 


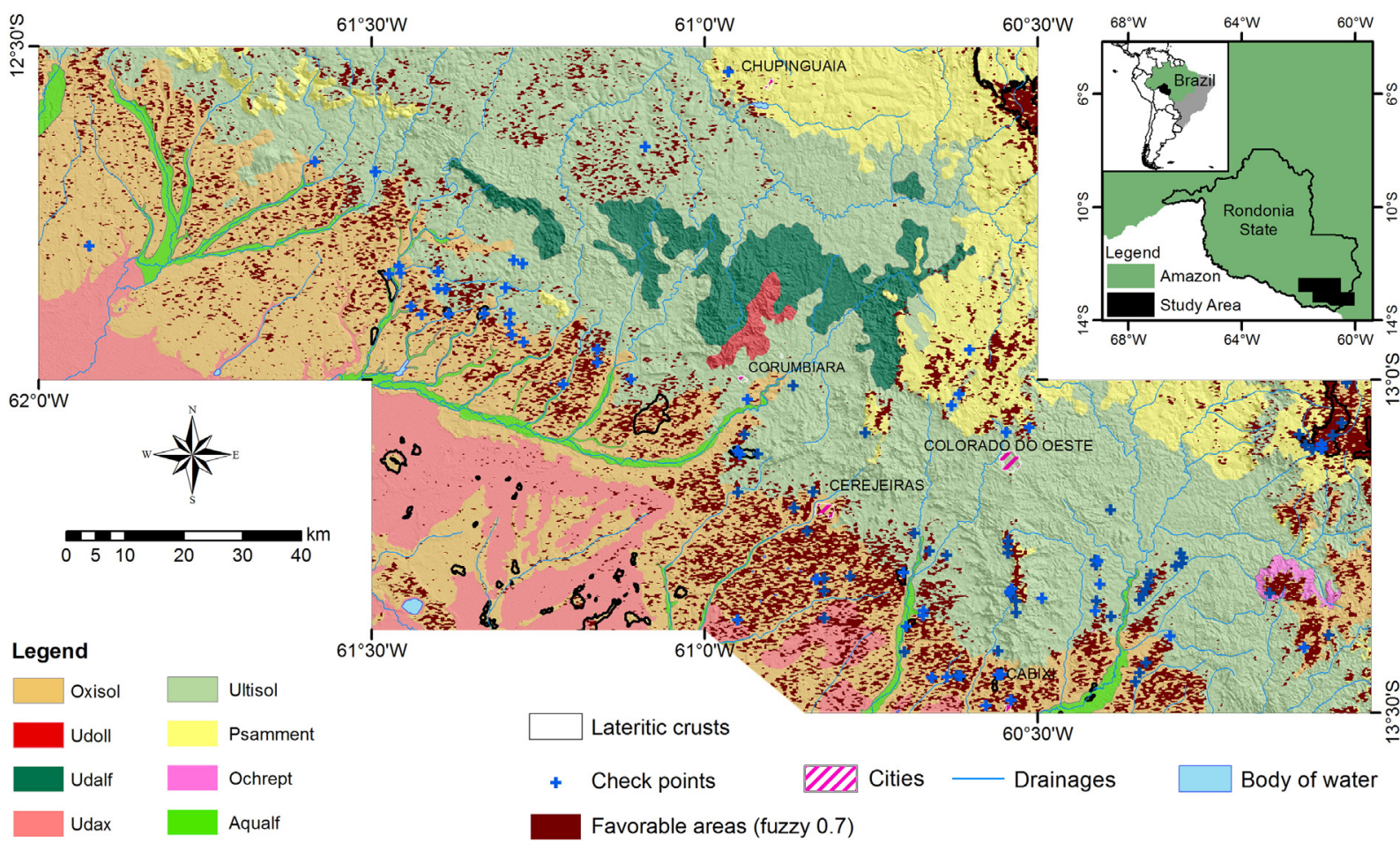

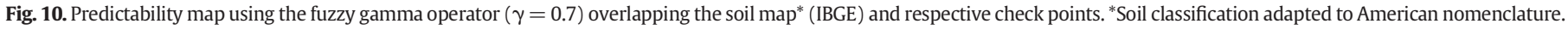

individualize the type of product (e.g., crusts, mottled horizon, oxisol) or response patterns of each individually.

\section{Conclusions}

The identification of lateritic crusts based on mathematic models applied to altimetric and airborne gamma-ray spectrometric data showed good reliability and good overlap with preexistent maps. From both methods applied, the fuzzy method was slightly more reliable than the Boolean method. Nevertheless, both methods can be used to identify potential areas for the occurrence of lateritic crusts and dismantling products, which will contribute significantly to geological mapping.

However, widespread and integrated support of the geological characteristics, regolith formation, and the relationship with relief are required to improve the interpretation. Areas that have high lithological variability with lateritic crusts or have gamma spectrometric responses that vary significantly must be evaluated carefully, as in some cases, high relief and the association with high values of eTh/K and eU/K could be associated with materials other rather than lateritic crust. This work highlighted that areas with low elevations and high values of eTh/K and eU/K show positive responses to the occurrence of lateritic crusts; however, field work is mandatory. The application of these mathematic models integrated with geomorphology, topography and remote sensing in other areas will enable the refinement of the application and increase its reliability, thus improving the model proposed in this work.

\section{Acknowledgments}

The authors thank the CPRM-DIGEOF for providing the aero geophysical data, the Applied Geophysics Laboratory (UnB) for the technical support and the reviewers for their useful comments. A.M.C. Horbe and A.M. Silva thank the Conselho Nacional de Desenvolvimento Científico e Tecnológico (CNPq) for the research scholarship.

\section{References}

Aleva, G.J.J., 1993. The CORLAT Handbook: Guidelines and Background Information for the Description of Laterite Profiles for Interdisciplinary Use, Issue 1. International Soil Reference and Information Centre, Brussels.

An, P., Moon, W.M., Rencz, A., 1991. Application of fuzzy set theory to integrated mineral exploration. Can. J. Expl. 27 (1), 1-11.

Anand, R.R., Paine, M., 2002. Regolith geology of the Yilgarn Craton, Western Australia: implications for exploration. Aust. J. Earth Sci. 49 (1), 3-162. http://dx.doi.org/10. 1046/j.1440-0952.2002.00912.x.

Bardossy, G., Aleva, G.J.J., 1989. The Amazon Basin: a discussion review. Travaux ICSOBA 19, 455-458.

Beauvais, A., 1999. Geochemical balance of lateritization processes and climatic signatures in weathering profiles overlain by ferricretes in Central Africa. Geochim. Cosmochim. Acta 63 (23-24), 3939-3957. http://dx.doi.org/10.1016/ S0016-7037(99)00173-8.

Bonham-Carter, G.F., 1994. Geographic Information Systems for Geoscientists: Modelling with GIS. Computer Methods in the Geosciences. 13. Pergamon Publications, Oxford.

Boulangé, B., Carvalho, A 1997. The Bauxite of Porto Trombetas. In: Carvalho, A Boulange, B., Melfi, A.J., Lucas, Y. (Eds.), Brazilian Bauxites. USP/FAPESP/ORSTOM, São Paulo, pp. 55-73.

Büdel, J., 1982. Climatic Geomorphology. Princeton University Press, New Jersey http://dx. doi.org/10.1002/esp.3290080216.

Burrough, P.A., Macmillan, R.A., Van Deursen, W., 1992. Fuzzy classification methods for determining land suitability from soil profile observations and topography. J. Soil Sci. 43 (2), 193-210. http://dx.doi.org/10.1111/j.1365-2389.1992.tb00129.x.

Butt, C.R.M., Zeegers, H., 1992. Regolith Exploration Geochemistry in Tropical and Subtropical Terrains. Handb. Explor. Geochem. vol. 4. Elsevier Science Publishers, Amsterdam.

Carranza, E.J.M., 2008. Geochemical Anomaly and Mineral Prospectivity Mapping in GIS. In Handb. Explor. Environ. Geochem. 11 pp. 189-246. http://dx.doi.org/10.1016/ S1874-2734(09)70001-4.

Carrino, T.A., Silva, A.M., Botelho, N.F., da Silva, A.A.C., 2011. Discriminação de áreas de espesso regolito do leste do Estado do Amazonas usando estatística multivariada, algoritmo hiperespectral e modelagem de dados espaciais. Rev. Bras. Geofis. 29 (1), $155-172$.

Cohen, J., 1960. A coefficient of agreement of nominal scales. Educ. Psychol. Meas. 20 (1), 37-46. http://dx.doi.org/10.1177/001316446002000104.

Costa, M.L., 1997. Lateritization as a major process of ore deposit formation in the Amazon region. Explor. Min. Geol. 6 (1), 79-104.

CPRM - Serviço Geológico Do Brasil, 2006. Projeto Aerogeofísico Sudeste de Rondônia: relatório final de levantamento e processamento dos dados magnetométricos e gamaespectrométricos. vol. 1. Lasa Engenharia e Prospeccões; Prospectors Aerolevantamentos e Sistemas, 27v, Rio de Janeiro.

da Silva, A.F., Barbosa, A.P., Zimback, C.R.L., Landim, P.M.B., Soares, A., 2015. Estimation of croplands using indicator kriging and fuzzy classification. Comput. Electron. Agric. 111, 1-11. http://dx.doi.org/10.1016/j.compag.2014.11.020. 
Darnley, A.G., Grasty, R.L., 1971. Mapping from the air by gamma-ray spectrometry. Can. Inst. Min. Metall. 11, 485-500.

Dauth, C., 1997. Airborne magnetic radiometric and sat imagery for regolith mapping in the Yilgarn Craton of Western Australia. Explor. Geophys. 28 (2), 199-203. http:// dx.doi.org/10.1071/EG997199.

Dent, D.L., MacMillan, R.A., Mayr, T.L., Chapman, W.K., Berch, S.M., 2013. Use of airborne gamma radiometrics to infer soil properties for a forested area in British Columbia, Canada. J. Ecosyst. Manag. 14 (1), 1-12.

Dickson, B.L., Scott, K.M., 1997. Interpretation of aerial gamma-ray surveys - adding the geochemical factors. AGSO J. Aust. Geol. Geophys. 17 (2), 187-200.

Duval, J.S., 1990. Modern aerial gamma-ray spectrometry and regional potassium map of the conterminous United States. J. Geochem. Explor. 39, 249-253. http://dx.doi.org/ 10.1016/0375-6742(90)90076-M.

Eddy, B.G., Graham, D.F., Bonham-Carter, G.F., Jefferson, C.W., 2006. Mineral Potential Analyzed and Mapped at Multiple scales-A Modified Fuzzy Logic Method Using Digital Geology. In: Harris, J.R. (Ed.), GIS for the Earth Sciences. Geological Associatino of Canada, Canada, pp. 143-162.

Graham, D.F., Bonham-Carter, G.F., 1993. Airborne radiometric data - a tool for reconnaissance geological mapping using a gis. Photogramm. Eng. Remote. Sens. 59 (8), 1243-1249.

Gregory, A.F., Horwood, J.L., 1961. A Laboratory Study of Gamma-Ray Spectra at the Surface of Rocks, Issue 85. Department of Mines and Technical Surveys, Ottawa.

Horbe, A.M.C., Da Costa, M.L., 1999. Geochemical evolution of a lateritic Sn-Zr-Th-Nb-YREE-bearing ore body derived from apogranite: the case of Pitinga, Amazonas Brazil. J. Geochem. Explor. 66 (1-2), 339-351. http://dx.doi.org/10.1016/S03756742(99)00002-3.

Horbe, A.M.C., Da Costa, M.L., 2005. Lateritic crusts and related soils in eastern Brazilian Amazonia. Geoderma 126 (3-4), 225-239. http://dx.doi.org/10.1016/j.geoderma. 2004.09.011.

Kogan, R.M., Nazarov, I.M., Fridman, S.D., 1969. Gamma-Ray Spectrometry of Natural Environments and Formation: Theory of the Method Application to Geology Dan Geophysics. Keter Press, Jerusalem.

Kotschoubey, B., Calaf, J.M.C., Lobato, a C.C., Leite, a S., Azevedo, C.H.D., 2005. Caracterização e gênese dos depósitos de bauxita da Província Bauxitífera de Paragominas, noroeste da Bacia do Grajú, nordeste do Pará/oeste do Maranhão. In: Marini, OJ.., Queiroz, E.T. de, Ramos, B.W. (Eds.), Caracterização de depósitos minerais em distritos mineiros da Amazônia. DNPM; CT/Mineral; ADIMB, Brasília, pp. 687-782

Kux, H.J.H., Brasil, A.E., Franco, M.S.M., 1979. Geomorfologia. Folha SD. 20 Guaporé: geologia, geomorfologia, pedologia, vegetação e uso potencial da terra. Brasil, Departamento Nacional de Produção Mineral. Projeto RADAMBRASIL, Rio de Janeiro, pp. $125-164$

Lagacherie, P., 2005. An algorithm for fuzzy pattern matching to allocate soil individuals to pre-existing soil classes. Geoderma 128 (3-4), 274-288. http://dx.doi.org/10. 1016/j.geoderma.2005.04.009.

Landis, J.R., Koch, G.G., 1977. The measurement of observer agreement for categorical data. Biometrics 33 (1), 159-174. http://dx.doi.org/10.2307/2529310.

Lucas, Y., Kobilsek, B., Chauvel, A., 1989. Structure, genesis, and present evolution of Amazonian bauxites developed on sediments. Travaux ICSOBA 19, 81-94.

McBratney, A., Mendonça Santos, M., Minasny, B., 2003. On digital soil mapping. Geoderma 117, 3-52. http://dx.doi.org/10.1016/S0016-7061(03)00223-4.

McFarlane, M.J., 1976. Laterite and Landscape. Academic Press, London.

McKenzie, N.J., Ryan, P.J., 1999. Spatial prediction of soil properties using environmental correlation. Geoderma 89, 67-94.

Minty, B.R.S., 1997. Fundamental of airborne gamma-ray spectrometry. AGSO J. Aust. Geol. Geophys. 17, 39-50.
Minty, B., 2011. Short note: on the use of radioelement ratios to enhance gamma-ray spectrometric data. Explor. Geophys. 42 (1), 116-120. http://dx.doi.org/10.1071/ EG10011.

Moreira, F.R.S., Almeida-Filho, R., Câmara, G., 2003. Spatial analysis techniques applied to mineral prospecting: an evaluation in the Poços de Caldas Plateau. Rev. Bras. Geosci. 33 (2), 183-190.

Nahon, D., Melfi, A., Conte, C.N., 1989. Presence d'un vieux système de cuirasses ferrugineuses latéritiques en Amazonie du Sud. As transformation in situ en latosols sous la forêt équatoriale actuelle. Comptes rendus de l'Académie des sciences. Série 2, mec. phys. chim. sci. univers, sci. Terre 308, 755-760.

Nykänen, V., Groves, D.I., Ojala, V.J., Eilu, P., Gardoll, S.J., 2008. Reconnaissance-scale conceptual fuzzy-logic prospectivity modelling for iron oxide copper-gold deposits in the northern Fennoscandian Shield, Finland. Aust. J. Earth Sci. 55 (1), 25-38. http:// dx.doi.org/10.1080/08120090701581372.

Pomerol, C., Lagabrielle, Y., Renard, M., Guillot, S., 2013. Princípios de geologia: técnicas, modelos e teorias. 14th ed. Bookman, Porto Alegre.

Quadros, M.L.E.S.; Rizzotto, G.J., 2007. Geologia e recursos minerais do Estado de Rondônia: texto explicativo do mapa geológico e de recursos minerais do Estado de Rondônia. Escala 1:1.000.000. CPRM, Porto Velho.

Rizzotto, G.J., 2010. Geologia e recursos minerais da folha Pimenteiras SD.20-X-D: texto explicativo do mapa geológico e de recursos minerais da folha Pimenteiras. CPRM, Porto Velho.

Rizzotto, G.J., 2012a. Geologia e recursos minerais da Folha Vilhena (SD.20-X-B): Sistema de Informações Geográficas-SIG: texto explicativo do mapa geológico e de recursos minerais da folha Vilhena, escala 1:250.000. CPRM, Porto Velho.

Rizzotto, G.J., 2012b. Petrologia e geocronologia do complexo máfico-ultramáfico Trincheira, sudoeste do Craton Amazônico: implicações tectônicas do mesoproterozoico 193 p. Thesis (PhD in Science) Instituto de Geociências, Universidade Federal do Rio Grande do Sul, Porto Alegre.

Tardy, Y., Roquin, C., 1998. Derive dês continents, paléoclimats et altérations tropicales Éditions BRGM, Orléans.

Taylor, G., 2008. Landscape and regolith. In: Scott, K.M., Pain, C.F. (Eds.), Regolith Science Springer, Dordrecht, pp. 31-43.

Taylor, G., Eggleton, R.A., 2001. Regolith Geology and Geomorphology. first ed. John Wiley \& Sons, Chichester.

Thomas, M.F., 1974. Tropical Geomorphology: A Study of Weathering and Landform Development in Warm Climates. John Wiley \& Sons, New York.

Torres, J., 2014. Lógica fuzzy: teoria da complexidade. Available at: http://www teoriadacomplexidade.com.br/ Accessed on: 10 nov. 2014

Tucker, C.J., Holben, B.N., Goff, T.E., 1984. Intensive forest clearing in Rondonia, Brazil, as detected by satellite remote sensing. Remote Sens. Environ. 15, 255-261. http://dx. doi.org/10.1016/0034-4257(84)90035-X.

Wilford, J., 2012. A weathering intensity index for the Australian continent using airborne gamma-ray spectrometry and digital terrain analysis. Geoderma 183-184, 124-142. http://dx.doi.org/10.1016/j.geoderma.2010.12.022.

Wilford, J.R., Bierwirth, P.N., Craig, M.A., 1997. Application of airborne gamma-ray spectrometry in soil/regolith mapping and applied geomorphology. J. Aust. Geol. Geophys. 17 (2), 201-216.

Zhu, A.X., Yang, L., Li, B., Qin, C., Pei, T., Liu, B., 2010. Construction of membership functions for predictive soil mapping under fuzzy logic. Geoderma 155 (3-4), 164-174. http:// dx.doi.org/10.1016/j.geoderma.2009.05.024.

Zimmermann, H.J., 1985. Fuzzy Set Theory and Its Applications. Kluwer Academic, Dordrecht. 